\title{
Dorota Wereda, Biskupi unickiej metropolii kijowskiej $w$ XVIII wieku, Wyd. Werset, Siedlce-Lublin 2013, ss. 376
}

Dorota Wereda jest znaną postacią w gronie polskich badaczy przeszłości. Jej prace, poświęcone głównie historii Kościoła unickiego, pojawiały się wielokrotnie jako ważne odsyłacze w publikacjach naukowych. Opublikowany dorobek naukowy autorki stanowi znaczący wkład w badaniach nad dziejami Kościoła i kultury staropolskiej. W jej dotychczasowym dorobku naukowym najważniejszym osiągnięciem była rozprawa doktorska Unicka diecezja brzeska w latach 1720-1795. Praca ta, wydana w 2014 roku pod tytułem Unicka diecezja włodzimiersko-brzeska (część brzeska) w XVIII wieku (Siedlce 2014), stanowi ważny wkład w poznanie dziejów Kościoła wschodniego na terenie dawnej Rzeczypospolitej.

W dość jednorodnym dorobku naukowym Doroty Weredy jej książka $B i$ skupi unickiej metropolii kijowskiej w XVIII wieku zajmuje miejsce szczególne. Praca w założeniach jej autorki miała być kompleksowym opracowaniem episkopatu unickiego metropolii kijowskiej w XVIII wieku. Zgadzam się, że wielu hierarchów nie posiadało swych biogramów w historiografii polskiej, ale nie oznacza to, że ich w ogóle nie ma. Autorka podaje liczne przykłady opracowań w historiografii ukraińskiej i innej, które ukazują w wielu aspektach hierarchię unicką tego okresu. Szkoda, że nie wykorzystała pracy A. G. Welykiego 3 Літопису Християнськоі Украйни wydanej w Rzymie w latach siedemdziesiątych XX wieku. Tomy: VI (1973) i VII (1975) są poświęcone niemalże wyłącznie XVIII-wiecznej hierarchii unickiej.

Poważne zastrzeżenia można mieć do wykorzystanej bazy źródłowej. Autorka rozprawy wykorzystała zasoby archiwów polskich, wileńskich i lwowskich. Pominęła jednak podstawowe archiwa do tego tematu, a mianowicie archiwum Kancelarii mitropolitów Grecko-uniatskiej Cerkwi w Rosji przechowywane w Państwowym Centralnym Archiwum Historycznym Rosji w Petersburgu oraz archiwa i biblioteki watykańskie. Jest to poważny mankament rozprawy, ponieważ w zasobach niewykorzystanych archiwów znajdują się pełne dane do życia i działalności władyków unickich. Nie mam natomiast zastrzeżeń co do 
wykorzystanych przez Autorkę źródeł wydanych drukiem i obszernej literatury przedmiotu.

Książka została podzielona na trzy rozdziały: pierwszy, złożony z dziesięciu części, omawia drogę 51 hierarchów do godności biskupiej; drugi, składający się z czterech części, koncentruje się na roli władyków unickich w życiu politycznym, społecznym i kulturowym; trzeci zaś, w sześciu częściach, omawia aktywność duszpasterską hierarchów unickich. Rozprawa składa się więc ze wstępu, trzech obszernych rozdziałów, zakończenia, wykazu skrótów i bibliografii. Brakuje natomiast streszczenia w językach obcych, indeksu osób, nazw etnograficznych i geograficznych.

Przechodzę do merytorycznej oceny poszczególnych rozdziałów. We wstępie pracy autorka wyjaśnia cele rozprawy i jej strukturę. Konstrukcja pracy nie wzbudza zastrzeżeń, jest przejrzysta i logiczna, podtytuły w poszczególnych rozdziałach, w porównaniu z ich treścią, nie wywołują kontrowersji.

Rozdział pierwszy ukazuje nam pochodzenie społeczne, terytorialne i familijne przyszłych biskupów. Docenić należy ogromny wysiłek D. Weredy przy ustaleniu miejsc urodzenia hierarchów. Rzeczywiście, większość z nich pochodziła z terenów białoruskich. Czterdziestu dziewięciu z nich było stanu szlacheckiego, ale Autorka książki zwraca uwagę na ich zróżnicowany status materialny i pozycję społeczną. Badaczka podjęła trud ustalenia koligacji rodowych biskupów oraz problem ich spokrewnienia. Słusznie zwraca uwagę na fakt ukształtowania kulturowego przyszłych hierarchów w rodzinach obrządku łacińskiego. Większość z nich urodziła się w zlatynizowanych rodzinach ruskich.

Z uznaniem należy ocenić wysiłki badawcze D. Weredy przy omawianiu procesu deprecjacji statusu społecznego i majątkowego rodzin, z których wywodzili się biskupi uniccy. Zawarta bogata faktografia ukazuje, że pod koniec XVIII stulecia biskupami zostawały osoby o coraz niższym statusie społecznym. Aspekt ten, tak szczegółowo przeanalizowany, posiada podstawowe znaczenie w zrozumieniu roli władyków unickich w życiu politycznym i społecznym.

Równie cenna jest analiza wykształcenia zwierzchników Cerkwi unickiej. Teologicznym wykształceniem legitymowało się 33 władyków, co stanowiło 64,7\% unickiej hierarchii. Zdobycie edukacji w łacińskich uczelniach teologicznych „wciągało” przyszłych biskupów w krąg kultury łacińskiej. Językiem konwersacji przestał być język wiernych - ruski, a obcy większości członkom Cerkwi unickiej - polski, łaciński, a nawet włoski. Zgadzam się z poglądem D. Weredy, że zdobyte wykształcenie, wiedza i umiejętności w kręgu kultury zachodnioeuropejskiej były nieadekwatne do potrzeb w pracy duszpasterskiej z wiernymi, ukształtowanymi w kulturze ruskiej. Podkreśliłbym dużą różnicę świadomościową między wiernymi a hierarchią unicką.

Dobrze też, że Autorka książki zwróciła uwagę na powiązania biskupów z zakonem bazyliańskim. Zgodnie z tradycją Kościoła wschodniego biskupi powinni pochodzić z klasztoru, w tym wypadku z klasztorów bazyliańskich. Nic też 
dziwnego, że biskupi angażowali się w życie monasterów, często doprowadzając ich do rozwoju albo upadku.

W wielu monasterach bazyliańskich w XVIII wieku nastąpiło rozprężenie życia wewnętrznego. Odstąpiono od ustalonego przez fundatorów i metropolitów kijowskich sposobu wyboru przełożonego monasteru. W przypadku jednego z największych z nich - Ławry Supraskiej - na godności przełożonych powoływano, wbrew woli mnichów, opatów spośród biskupów pińskich i włodzimierskich. Biskupi ci, po objęciu władzy w klasztorze, wykorzystywali jego możliwości ekonomiczne do prowadzenia wytwornego stylu życia. Kronikarz Ławry Supraskiej tak opisywał konsekwencje bezpośrednich rządów biskupich.

Lecz gdy w ciągu czasu niedbalstwo powodem było, że wzmiankowane prawo zapomniane zostało, przez co klasztor wszelką ruinę swych praw y funduszów doznał, które dla przepychu opatów supraskich, arcybiskupia lub biskupia godnością ozdobionych, na utrzymanie ich koni, pojazdów, srebrnych sprzętów i licznego orszaku służących trwonione i niszczone były, a następnie zakonnikom nikczemna zostawała się żywność y ruchomość klasztorna y sprzęty kościelne ze wszystkim opuszczone $(. . .)^{1}$.

Były też i pozytywne przykłady. W okresie pobytu w tym klasztorze metropolity Leona Kiszki rozpoczęto od roku 1728 wznoszenie pomieszczeń klasztornych ze strony południowej, zachodniej i wschodniej. Prace budowlane były prowadzone za archimandryty Jerzego Bułhaka, biskupa pińskiego (1730-1769). Inwestycje te zakończono dopiero $\mathrm{w}$ drugiej połowie XVIII wieku. W rezultacie powstał cały zespół klasztorny z pałacem opatów, budynkami braci zakonnych, bramą-dzwonnicą i wieloma pomieszczeniami gospodarczymi. W 1771 roku pomalowano wnętrze świątyni i wykonano sztukaterię. Zamalowano w ten sposób białą farbą XVI-wieczne bizantyjskie freski. Wnętrze świątyni otrzymało rokokowy wystrój sztukatorski, wzbogacony malowidłami o innym aniżeli bizantyjski charakterze. Od 1695 roku działała na terenie klasztoru drukarnia i papiernia. Do 1803 roku z drukarni supraskiej wyszło ok. 350 tytułów, w tym sto wydanych cyrylicą ${ }^{2}$.

Nie mam zastrzeżeń do fragmentu rozprawy ukazującego wpływ elementu świeckiego (króla, magnaterii, dostojników świeckich i duchownych) na obsadę katedr biskupich. Praktyka obsadzania katedr unickich, jak udowodniła D. Wereda, nie zawsze była zgodna z interesami Cerkwi. Duży wkład pracy Autorka książki wniosła w przedstawienie sposobu nominacji biskupów włodzimiersko-brzeskich oraz wpływu na ich wybór króla i Radziwiłłów. Wspomniane prawo

1 „Kronika Lawry Supraskiej”, Archeograficzeskij Sbornik Dokumientow, t. IX, Wilno 1870, s. 337.

2 M. Cubrzyńska-Leonarczyk, Oficyna supraska 1695-1803, Warszawa 1993. 
„podawania” i „ktitorstwa” obowiązywało, ale ostateczną zatwierdzającą decyzję podejmował papież. Podana przez autorkę rozprawy teza, że w celu łatwiejszego awansu wierni obrządku łacińskiego wstępowali do zgromadzenia bazylianów nie znajduje potwierdzenia. Pojedyncze przypadki konwersji osób z obrządku łacińskiego na unicki miały różne uzasadnienia.

Duże walory poznawcze posiada drugi, obszerny rozdział poświęcony postawie hierarchii unickiej wobec króla i Rzeczypospolitej. Biskupi obrządku wschodniego cieszyli się dużym prestiżem wśród wiernych i z tego powodu byli wykorzystywani przez władze Rzeczypospolitej do pozyskania wsparcia politycznego i zachowania lojalności wobec państwa. Wereda po raz pierwszy podjęła próbę ukazania zaangażowania hierarchii w obradach sejmików i ich wpływ na kształtowanie się lokalnych środowisk opiniotwórczych.

Wypada w pełni zgodzić się z opinią D. Weredy, że biskupi uniccy wielokrotnie dawali wyraz swej patriotycznej postawy wobec Rzeczypospolitej i odpowiedzialności za postawę swych wiernych. Autorka pracy przywołuje tu czasy konfederacji barskiej, zapobieżenie buntowi na obszarach województw południowo-wschodnich w latach Sejmu Wielkiego. Rola władyków ruskich była szczególnie istotna w drugiej połowie XVIII wieku, w dobie rozbiorów. Poparcie walki o niepodległość w czasie powstania kościuszkowskiego czy nieuczestniczenie w buntach na Ukrainie można było uzyskać m.in. dzięki apelom hierarchii unickiej. Doceniając postawę władyków unickich ich metropolita ostatecznie został dopuszczony do senatu, w którym zajmował miejsce po episkopacie łacińskim.

Niemniej intersujący i napisany z doskonałym rozeznaniem sytuacji jest fragment rozdziału drugiego ukazujący życie towarzyskie i pozycję społeczną biskupów unickich. Magnateria świecka bardziej akceptowała ich obecność w kręgach towarzyskich i chętnie robiła $\mathrm{z}$ nimi interesy finansowe aniżeli episkopat łaciński. Niechęć ze strony tych ostatnich wobec biskupów unickich doprowadziła do traktowania unitów jako katolików drugiej kategorii. Nie mogę w tym kontekście zaakceptować podglądu D. Weredy, że udział władyków unickich w ceremoniach koronacyjnych obrazów Matki Bożej stanowi przykład ich przynależności do kultury sarmackiej. Jeżeli nawet tak było, to dokładny opis uroczystości religijnych z udziałem episkopatu łacińskiego i unickiego jednoznacznie wskazywał postępującą latynizację obrządku unickiego.

Styl życia władyków unickich w ich prywatnych lub cerkiewnych rezydencjach rzeczywiście nawiązywał do zwyczajów znanych z rezydencji magnackich, ale nie oznaczał dorównania pozycji społecznej magnaterii. Mankamentem tej części rozprawy jest całkowite pominięcie relacji biskupów unickich z prawosławnymi władykami białoruskimi (Serafinem Połchowskim, Sylwestrem Czetwertyńskim, Arseniuszem Berło, Józefem i Hieronimem Wołczańskim oraz Jerzym Konisskim). Problem ten szczegółowo omawiam w pracy Diecezja białoruska w XVII i XVIII wieku, Białystok 2008, s. 142-253 i monografiach poszczególnych biskupów mohylewsko-witebsko-orszańskich. 
Z punktu widzenia historyka Kościoła za najcenniejszy uznaję trzeci rozdział rozprawy o aktywności duszpasterskiej biskupów unickich. Autorka omawia udział biskupów w soborach lokalnych (diecezjalnych) oraz ich zaangażowanie w wizytacje parafialne. Trzeba się zgodzić z konkluzją D. Weredy, że brak systematycznych wizytacji i realizacji zaleceń pokontrolnych doprowadził do fatalnego stanu materialnego i moralnego duchowieństwa parafialnego. Nie mogę natomiast zaakceptować stwierdzenia Autorki pracy odnośnie miejsca kapituł w systemie zarządzania diecezją. Kapituły to zlatynizowane kryłosy, których zadaniem była pomoc w kierowaniu eparchią. Kryłos był organem władzy administracyjnej i sądowniczej diecezji (od greckiego słowa kléros - duchowieństwo katedralne). Kryłosy znajdowały się wyłącznie w stolicach diecezji. W ich skład wchodzili prezbiterzy cerkwi parafialnych miasta stołecznego biskupstwa. Na ich czele stał protoprezbiter, zwany często protopopem. Do obowiązków kryłoszan należało odprawianie nabożeństw i pełnienie funkcji duszpasterskich w cerkwi katedralnej oraz asystowanie biskupowi $\mathrm{w}$ jego obowiązkach religijnych. Członkowie kryłosu zasiadali w sądzie biskupim, administrowali jego majątkami, zarządzali mieniem nieruchomym diecezji. Z kryłoszan wybierano również namiestników władyków. Namiestnik w okresie nieobecności władyki mógł czasowo zarządzać diecezją lub jej częścią.

Doceniam duży wkład D. Weredy przy wskazaniu roli władyków unickich w rozwoju edukacji podległego im kleru, tworzeniu placówek oświatowych, misyjnych, zabezpieczeniu ekonomicznym diecezji, dekanatów, monasterów i parafii. Oni też byli odpowiedzialni za latynizację swego obrządku i rozwoju kultu maryjnego, np. Matki Bożej w Żyrowicach. Należałoby dodać, że szczególnie w drugiej połowie XVIII wieku byli oni propagatorami kultu ikony Matki Bożej Częstochowskiej. Kult kopii tej ikony był w tym czasie bardzo popularny ${ }^{3}$. Nie mam zastrzeżeń do treści podnoszącej udział hierarchii unickiej w przebudowie świątyń w stylu barokowym, zmian w wystroju wnętrza cerkwi, wprowadzania łacińskich modlitewników i kultu świętych czy wprowadzenia języka łacińskiego i polskiego do kontaktów z wiernych i do nabożeństw. Na miejscu Autorki pracy tego znanego procesu latynizacji obrządku unickiego nie nazywałbym jednak ,przełączaniem” kultury z rejestru bizantyjsko-prawosławnego na rejestr rzymsko-łaciński. Unici w tym czasie daleko odeszli od tradycji wschodniej, a opisywany przez D. Weredę proces jest dostosowywaniem architektury i praktyk religijnych do wymogów postanowień synodu zamojskiego.

Synod zamojski wnosił nowe wymogi w zakresie głoszenia Słowa Bożego i katechizacji oraz sakramentów: chrztu, bierzmowania, eucharystii, pokuty, namaszczenia świętymi olejami, kapłaństwa i małżeństwa. Zmiana w sposobie

3 Por. A. Mironowicz, Księga cudów przed ikonq Matki Bożej Waśkowskiej dokonanych, Białystok 2012. 
udzielania sakramentów wynikała z dążenia do latynizacji wyznawców obrządku wschodniego. Zarządzenia soborowe dotyczyły również dyscypliny wśród duchowieństwa unickiego, a nawet episkopatu. Warte podkreślenia jest wskazanie konsekwencji wprowadzenia w życie postanowień zamojskich na funkcjonowanie monasterów bazyliańskich. Utworzenie dla nich jednej kongregacji było ciosem w ich autonomię i we wschodnią tradycję życia monastycznego.

Metropolita unicki, realizując owe synodalne ustalenia, nakazał dokonanie nowej redakcji ksiąg liturgicznych oraz zakazał, pod groźbą kar dyscyplinarnych, używania dotychczasowych - prawosławnych. Temu celowi służyło wydanie katechizmu Sobranie pripadkow kratkoje i duchownym osoba potrebnoje w Supraślu w 1722 roku. Był pierwszy krok w realizacji postanowień synodalnych. Praca ta wiernie oddaje charakter postanowień synodu zamojskiego, z uwzględnieniem wszystkich łacińskich nowości wprowadzonych do Cerkwi unickiej. W świetle tego opracowania wyłącznie papieżowi przyznano prawo odpuszczania wielu grzechów, przyjęto katolicką naukę o czyśćcu i pokucie, ważność komunii pod jedną postacią i przyznano prawo odprawiania kilku nabożeństw przy jednym ołtarzu przez tego samego kapłana. Ogromną rolę w procesie wprowadzaniu zmian w księgach liturgicznych odegrał metropolita Leon Kiszka. Przyjęcie unii musiało wprowadzić liczne zmiany w architekturze i sztuce cerkiewnej, które po 1720 roku jeszcze bardziej upodobniały cerkwie do kościołów łacińskich. Koronacje cudownych obrazów były elementem latynizacji unitów.

W zakończeniu rozprawy D. Wereda podsumowała swoje badania i wskazała na rolę biskupów unickich w zmianach kulturowych i etnonarodowych wielu społeczności. Zasygnalizowany, a szkoda, że nierozwinięty, problem konsekwencji wprowadzenia unii brzeskiej na zmiany kulturowe wymaga głębszych studiów. Niepodjęcie tego zagadnienia nie deprecjonuje rozprawy i nie wpływa na jej pozytywną ocenę. Pracę uzupełnia aneks zawierający wykaz biskupów i księży unickich $\mathrm{z}$ dodaniem istotnych informacji dotyczących zamieszczonych w wykazie osób.

Pomimo powyższych uwag, moja opinia o pracy Doroty Weredy jest w pełni pozytywna. Jej główną wartością jest przedstawienie charakterystyki i roli biskupów unickich w XVIII wieku. Oceniając recenzowaną książkę należy zwrócić uwagę na połączenie w niej wielu elementów o charakterze historycznym, teologicznym, prawnym i kulturowym. Ażeby ten cel zrealizować, autorka była zmuszona sięgnąć do kwestii prawnych, religijnych i historycznych, dogłębnie zrozumieć uwarunkowania polityczne towarzyszące działalności władyków unickich. Wieloaspektowy ogląd ich aktywności pozwolił badaczce zweryfikować panujące w literaturze naukowej niektóre opinie. Książka D. Weredy wskazuje na ogromną rolę hierarchii unickiej w ukształtowaniu obrazu Cerkwi unickiej w XVIII wieku.

Praca Doroty Weredy jest jedyną, która w sposób całościowy ukazuje hierarchię unicką, jej pochodzenie społeczne, powiązania familijne, stan majątkowy, 
wykształcenie, okoliczności wyboru na ordynariuszy diecezji oraz ich rolę w życiu politycznym, społecznym, religijnym i kulturalnym. Autorka w swej głębokiej analizie nie traci $\mathrm{z}$ oczu żadnego $\mathrm{z}$ istotnych problemów i zdaje sobie sprawę ze zmienności czynników, które decydowały o zaangażowaniu hierarchii unickiej w życie społeczno-polityczne. Warto podkreślić, że wieloletni trud Autorki pracy zakończył się pełnym sukcesem. Wyrazem tego osiągnięcia jest książka Biskupi unickiej metropolii kijowskiej w XVIII wieku. 